\title{
SCIENCE POLICY FOR BRITAIN
}

T HE first report of the Council for Scientific Policy is concorned with the definition of objectives for the years ahead rather than with the solution of specific problems. In his introduction to the report (Report on Science Policy, H.M.S.O.), the chairman of the Council, Sir Harrie Massey, states that he and his colleagues have not found it easy to "ensure the development of science in an environment of relatively slow economic growth". $\mathrm{H} \Theta$ says that there must be a fuller understanding of the mechanism and the benefits of scientific growth, and describes his Council's first report as "our preliminary analysis".

The Council explains its concern for the principles of science policy" by saying that "science needs confidence for its development", which means, in turn, "widespread public confidence in science as a necessary, desirable and well-managed investment for the future, and a main enablement for the attainment of national objectives". It goes on to say that the growth of the scale of science has made a self-conscious concern for its conduct more urgent, and announces, in a somewhat delphic manner, "the temptation may have to be resisted to throw all our limited resources into the exploitation of present knowledge, thus cutting back our capacity to advance in the future".

Strictly speaking, the Council is concerned simply to advise the Secretary of State for Education and Science, which implies responsibility for the research councils and a right to a hearing from the University Grants Committee.

At the beginning of its first report, the Council sets out to exorcize "the misconception that the advance of scientific knowledge itself can be directed from the centre. This would be to misunderstand the original and spontaneous nature of science. The advance of scientific knowledge cannot solely be achieved by the arbitrary selection of national goals and by committing resources of men and money to them".

The objective of science policy is not to direct the advance of science, but to "maintain the environment necessary for scientific discovery; to ensure the provision of a sufficient share of the total national resources to ensure that there is a balance between fields and that others are not avoidably neglected; to provide opportunities for inter-fertilisation between fields, and between the scientific programmes of nations". It is for universities and research councils to decide what scientific objectives to aim at. The task which the Council sets itself is to look ahead nationally and internationally, to relate scientific activities to others competing for resources, and to "provide the basis for national acceptance of the scale of resources which are needed for the healthy' evolution of science".

The Council refers to the recent argument about the proper level of government expenditure on research and development by the understatement that "it has been represented to us that the capacity of the national economy' will not permit the growth of research council expenditure at present rates-about 13 per cent annually in roel terms, or a doubling every six years-within the limits of planned national expenditures. This situation was not before our predecessors, and so far as we are aware is not yot faced by other countries in the van of scientific advance". The Council accepts that there must at some stage be a levelling off. "The question at issue is when, and at what rate, and on what eriteria, the levelling-off of the growth rate should take place". With something akin to resignation, the Council goes on to say that a constructive solution should be one that maintains the morale of scientists and the vitelity of science even on "relatively" stable economic resources", which in turn implies greater flexibility in the management of research and development.

The Council has a powerful argument in support of planning ahead. In discussions with the research councils, it has apparently emerged that existing commitments to the recipients of grants would make necossary a substantial increase of expenditure in the financial year 1966-67. The forward commitments of the Medical Research Council are apparently such that even if there wore no new grants for biological research in the universities in the current financial yoar, expenditure in 1966-67 would be 15 per cent greater than in the previous year. The report argues that in such a situation, comparatively small restrictions of the funds available for research can grievously hamper the starting of new projects. (This is an echo of one of the recurrent themes of the recent report of the U.S. National Academy of Sciences on the condition of physies in the United States.) In the event, the Council has settled for an increase in 1966-67 of 18.7 per cent above the $\$ 19.07$ million spent by the research councils in its charge during 1965-66, although the increase in cost to public funds will amount only to $12 \cdot 2$ per cent in real terms, partly because of the offsetting effect of recent. restrictions of capital expenditure.

For the time being, however, the Council is evidently more concerned to establish criteria for determining the strategy of science than with haggling about decimals of a per cent. Thus the Council is working with the researeh councils on plans to estimate in advance the consequences of any "tapering off" in research expenditure that there may eventually be.

The Council is also planning to keep a careful watch on the development of higher education in science, and it holds that "one of the important parameters for scientific growth should be the expansion of university teaching functions in science and technology, especially at the more advanced levels . . . we consider that the volume of research conducted in universities should keep pace with the growth in teaching functions".

So as to know what "rates of growth of science are permissible in the universities and the research councils without creating serious problems for the intake of highlyqualified manpower into industry and for the long-term quality of science teaching in the schools", the Council has persuaded the Committee on Manpower Resources to establish a working party under Prof. Michael Swann.

The improvement of the "scientific environment" is given as another goal. The recommendation of the subcommittee under Prof. B. H. Flowers that expenditure on university computers should run at about $£ 3$ million a year has clearly persuaded the Council that there will be benefit in other similar exercises. Thus Sir Gordon Sutherland has been asked to lead a working party to find out whether universities could make better use of tho equipment of the public research establishments, while Dr. J. C. K. Kendrew has been asked to lead a group reviewing "the problem of the development of Molecular Biology in the United Kingdom". Finally, Sir Harrie Massey will be the chairman of a group which is continually to review the conduct of international relations in science. In this connexion, the report declares there to be a dis. tinction "between measures which facilitate the natural and essential interchange of men and ideas which is at the heart of science, and the creation of specific co-operative arrangements for the solution of particular scientific prohIems". The Council is in favour of arrangements of the first kind, but evidently determined to look most critically at the second. 